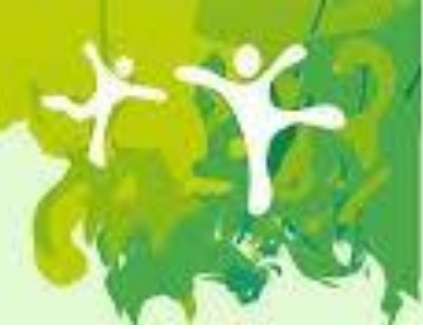

\title{
INFLUENCIA FAMILIAR NA OPÇAO DA EXPERIENCIA MATERNA ENTRE ALEITAMENTO MISTO E/OU PREDOMINANTE
}

\section{Pôster}

Autores deste trabalho:

Gabriela Van Der Zwaan Broekman Castro: Universidade Federal de São Carlos

Mayara Caroline Barbieri: Universidade Federal de São Carlos

Beatriz Faccio: Universidade Federal de São Carlos

Flavia Abreu: Universidade Federal de São Carlos

Carla Regina Correa: Universidade Federal de São Carlos

Monika Wernet: Universidade Federal de São Carlos

Giselle Dupas: Universidade Federal de São Carlos

Área do Trabalho: Enfermagem pediátrica

Número de inscrição: 5367

Data da submissão:30/08/2016 às 17:26

\section{Justificativa}

O desmame precoce, pode ser caracterizado como interrupção do aleitamento materno (AM) antes dos seis meses de vida. As condutas adotadas pela mulher na prática do AM articulam-se com a influência exercida pelos familiares. O AME é um desafio nacional e impacta alimentação, desenvolvimento e diminuição da morbimortalidade infantil.

\section{Objetivo(s)}

Analisar experiência materna de aleitamento misto e/ou predominante, com atenção à influência das interações familiares.

\section{Método(s)}

Estudo qualitativo, descritivo, que utilizou como referencial teórico o Interacionismo Simbólico (IS) e metodológico a pesquisa de narrativa. Os sujeitos foram mães de lactentes com até 6 meses de idade e em aleitamento materno misto, cujos filhos não possuíssem contraindicação do aleitamento materno e não tivessem saído da maternidade 
com prescrição de fórmulas; adscritas a uma Unidade de Saúde da Família do interior paulista. Foram entrevistadas 12 participantes.

\section{Resultado(s)}

Caracterizou-se a experiência materna de aleitamento misto e/ou predominante em duas unidades temáticas: -Opção pelo AM misto e/ou predominante - O ganho/perda de peso balizam a tomada de decisão quanto à forma de alimentação da criança. Prioriza-se o AME, porém atrelar outro tipo de leite como algo temporário/secundário por vezes demonstrou-se necessário. A distância e impossibilidade de amamentar durante o emprego são limites para a manutenção do AME. As intercorrências mamárias foram responsáveis por estresse físico/emocional, levando as mães a introduzir outro leite, sofrendo com tal decisão. -Família e AM misto e/ou predominante - familiares exercem influência na amamentação, mostrando-se ora favoráveis e ora contrários à introdução de outros leites e/ou líquidos. O incentivo ao AME foi significativo para as mulheres, sendo fornecido por meio de falas e atitudes dos familiares, em especial sogra, mãe e companheiro.

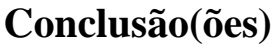

O aleitamento misto e/ou predominante é uma forma de cuidado ao filho, visando sua proteção. Nesse contexto, realizam interações consigo mesmo e com outros núcleos (filho, família e profissionais de saúde), ressignificando o aleitamento e modificando ações relativas à nutrição. Nessas interações a mulher avalia seu papel enquanto mãe, ancoradas nas próprias representações e no que é esperado pela sociedade. Concernente à família, encontra elementos como a historicidade/mitos relacionados ao ato de amamentar, influenciadores na opção de como alimentar o filho. 